\title{
ANÁLISIS DE COMUNIDADES \\ CERRADAS DE FACEBOOK PARA \\ MEJORAR EL DESARROLLO DEL \\ VOCABULARIO EN INGLÉS COMO \\ LENGUA EXTRANJERA A TRAVÉS DEL MÉTODO CLASE INVERTIDA
}

\section{ANALYSIS OF CLOSEID FACEBOOK \\ COMMUNITIES TO ENHANCE \\ VOCABULARY DEVELOPMENT IN \\ ENGLISH AS A FOREIGN LANGUAJE THROUGH FLIPPED CLASSROOM METHOD}

Manuel Alejandro Salazar Chica', Germán Enrique Pérez Tamayo², Diana Katherine González Ocampo ${ }^{3}$ Gonzalo Romero Martínez ${ }^{4}$ 


\section{RESUMEN}

Esta comunicación reitera la fundamental importancia que hoy se le concede a las herramientas Tecnológicas para en los procesos de enseñanza aprendizaje es por ello que el objetivo general de esta investigación es: crear ambientes de aprendizaje para incrementar el vocabulario en inglés de los estudiantes del grado $8^{\circ}$ de la institución educativa María Antonia Ruiz, a través de la clase invertida y los grupos cerrados de Facebook. De acuerdo a los resultados obtenidos después de la aplicación del Test Diagnóstico mediante la

$1 \quad$ Manuel A. Salazar es Licenciado en Lenguas extranjeras de la Uceva, Especialista en Administración de la Informática Educativa y Magister en Gestión de la Informática Educativa de la Universidad de Santander UDES. Trabaja como Profesor tiempo completo en el Programa de Lenguas Extranjeras con énfasis en Inglés de la Unidad Central del Valle del Cauca, Uceva, en Tuluá Colombia. Es miembro activo del grupo de investigación en Lingüística aplicada de la misma universidad y actualmente desarrolla investigación sobre el uso de la tecnología en la enseñanza y el aprendizaje de inglés. Correo: masalazar@ uceva.edu.co Orcid ID: https://orcid.org/0000-0001-5633$\underline{7268}$

2 Germán E. Pérez es Licenciado en Lenguas modernas de la Universidad del Quindio, Especialista en Administración de la Informática Educativa y Magister en Gestión de la Informática Educativa de la Universidad de Santander UDES. Trabaja como Profesor hora catedra en el Programa de Lenguas Extranjeras con énfasis en Inglés de la Unidad Central del Valle del Cauca, Uceva, y es docente de la I.E. María Antonia Ruiz en Tuluá Colombia. Correo: gperez@uceva.edu.co Orcid ID: https://orcid.org/0000$\underline{0001-6312-8843}$

3 Diana Katherine González O. Es magister en Enseñanza del Inglés como lengua extranjera de la Universidad Internacional Iberoamericana de Puerto Rico. Trabaja como Profesora en el Programa de Lenguas Extranjeras con énfasis en Inglés de la Unidad Central del Valle del Cauca, Uceva, en Tuluá Colombia. Es miembro activo del grupo de investigación en Lingüística aplicada de la misma universidad y actualmente coordina la línea de investigación: Procesos de aprendizaje de las lenguas extranjeras. Correo: dkgonzalez@uceva.edu.co Orcid ID: https://orcid.org/0000-0002-4523-0673

4 Gonzalo Romero. Es magister en Educación Bilingüe de la Universidad Internacional de la Rioja. Trabaja como

docente tiempo completo en el Programa de Lenguas Extranjeras con énfasis en Inglés de la Unidad Central del Valle del Cauca, Uceva, en Tuluá Colombia. Es miembro activo del grupo de investigación en Lingüística aplicada de la misma universidad y actualmente coordina la línea de investigación: Bilingüismo. Correo: gromero@uceva.edu.co Orcid ID: https://orcid.org/0000-0002-6097-5104 prueba internacional KET en la que se midió el conocimiento de vocabulario, los estudiantes presentaron falencias de acuerdo al nivel escolar y a los lineamientos dados por el Ministerio de Educación y el Marco común Europeo de Referencia; Por ende, este estudio buscó fortalecer la comprensión de vocabulario en dicho idioma a través de la utilización de la clase invertida y de herramientas y recursos web tales como Quizlet y YouTube que fueron compartidos a los estudiantes a través de un grupo cerrado de Facebook. Después de la implementación, se pasó a la validación del proceso mediante una segunda aplicación del examen KET con la que se pudo evidenciar: mejor conocimiento de vocabulario de los estudiantes antes de la clase, una mayor participación en las actividades en clase y finalmente una notable mejoría en los resultados del segundo examen aplicado. Además, el estudio reveló una nueva estrategia extra clase para mejorar una deficiencia común entre los aprendices de una segunda lengua como es la falta de conocimiento de vocabulario

\section{ABSTRACT}

The following paper reports the results of a quantitave research study sought to analyze the incidence of closed Facebook communities to enhance English vocabulary development in high school students by using the Flipped classroom method. Technological tools are a fundamental part of the English teaching-learning process. The use of virtual strategies facilitate teaching and give students virtual learning environments where they can have real contact with the English speaking world. Therefore, the need of studying different virtual resources and their effectiveness in $21^{\text {st }}$ century teaching practices. Low vocabulary level mainly in matching strategies and completing sentences was detected after the results of the KET diagnostic test applied to students. The results evidenced the need of implementing a didactic sequence based on the Flipped Classroom method. Thus, a series of 
ten sessions by means of the implementation of closed Facebook communities were developed. Quizlet tool was also used, in order to keep track of students' participations and classroom scoring. After the implementation, a final KET test was applied. The final results showed $34 \%$ improvement in matching and $33.5 \%$ completing sentences components. Similarly, the final test results evidenced students' ability to find an unknown word in reading paragraphs. The data proved the positive incidence of Facebook closed groups and flipped classroom to develop vocabulary level in English as a foreign language.

\section{KEYWORDS Closed Facebook groups,} Flipped classroom, improvement, vocabulary, web applications, quizlet.

\section{INTRODUCTION}

In Colombia, the need to learn a foreign language is increasingly urgent due to the social and commercial interaction that our country has had in recent decades due to the concept of Globalization. The National Government, through the Ministry of Education, has proposed the National Bilingualism Plan 2004-2019 as a contingency plan, taking into account the need for training in English as a Foreign Language. This plan is based on the Common European Framework of Reference (CEFR) for languages' learning, which determines proficiency levels in a second language or foreign language worldwide. For this reason, it is important to highlight the importance of the accompaniment and in some cases strengthening of the levels of competence within the public and private educational institutions of the country.

One of the quality controls proposed by the National Ministry of Education (MEN) to educational institutions is Saber 11 English test. This test measures the knowledge acquired by students in different subjects and specifically in the English subject, it measures reading and vocabulary skills in levels A1, A2, B1 and $B+$. With the intention of improving the level of proficiency in the English Foreign language it is necessary to reinforce the acquisition of vocabulary in students in secondary school, improving reading comprehension within class activities, which will result in optimal results in Saber 11.English test.

In light of this situation, the current research project began with the selection of the 8th grade at Maria Antonia Ruiz School to apply a diagnostic test to confirm the level of vocabulary in the comprehension of texts according to the international Key English Test (KET). Next, the research group contextualizes the vocabulary according to the CEFR and Guide 22 of the MEN; Then, the population is aware of the importance of using Information and Communication Technologies ICTs in teaching processes and implements the process of improvement in the acquisition of vocabulary with the use of web resources taking advantage of the benefits offered for their work at home before class (Flipped Classroom), such as: varied information, instructional flexibility, increased motivation inside and outside the classroom, attractive audiovisual activities, interaction on the web and finally all the process is complemented by their respective activities in the classroom, which allows the students to get into the classroom with a prior knowledge that allows a better understanding of the activities proposed by the teacher in class.

Consequently, the research proposes as a method the Flipped Classroom through the closed groups of Facebook with the objective of sharing web resources so that the students can do a learning process with tools such as Quizlet and YouTube. Likewise, within the implementation process the main limitation is the Internet connectivity taking into account that the project requires a connection by both the 
teacher and part of the students who in most cases do not have the service in home and must pay for the service because in many moments the school does not have a good connectivity either.

Finally, despite the limitations and difficulties found, an effective implementation process could be carried out, which could be validated at the end with a second version of the international KET exam and a possible solution to the deficit that students have in vocabulary learning was evidenced of the foreign language; Likewise, it allowed an improvement both in class and in the results obtained in the second test. This whole research process also aims to increase reading skills in the target language, thus increasing the results so that there is a smaller gap between the standard proposed by the Ministry of Education and the current results in La Prueba Saber 11.

\section{THEORETICAL FRAMEWORK}

The current research project at Institution Educative María Antonia Ruiz of Tuluá Valle bases its study on analyzing the influence of the Flipped Classroom and the closed groups of Facebook in the learning of vocabulary of the foreign language English, in the eighth grade students of the school.

For the current study, some theoretical referents will be taken who base their statements on the importance of the Flipped Classroom, which is a teaching approach that has as a principle in the first instance a pre-class work of the students at home that allows to obtain some prior knowledge before reaching the meeting with his teacher, and then, they can carry out practical activities in order to develop the skills taking into account the same knowledge previously studied. Bergmann and Sams (2014) state that The flipped classroom is a pedagogical approach in which direct instruction moves from the collective learning space to the individual learning space, and the resulting space is transformed into a dynamic and interactive learning environment in which the educator guides to students as the concepts are applied and can participate creatively in the subject. (p.18)

Likewise, taking into account the rise in the use of the ICTs, this approach is strengthened by enabling advance knowledge through all the resources provided by Internet access. Tourón and Santiago (2013) point out that it is a didactic method in which students learn new content through video tutorials online, usually at home; and what used to be "homework" (assigned tasks), are now done in the classroom with the teacher offering more personalized guidance and interaction with the students. (p.14)

Besides, ICTs become the main way to make the Flipped Classroom possible, not only because of students' desire to make use of them, but also to allow inquiries from home without the need of a tutor or a teacher, as well as a main role for the student in their learning process. Jordán (2014) states that the flipped classroom allows to take advantage of the rise of new technologies to improve student learning through the exchange of teacher-student roles: the student begins the study of the subject outside the classroom and deepens it in a face-to-face session with the teacher's support and the discussion with the rest of the classmates. (p.2) 
Finally, the key point of the importance of the Flipped Classroom is the educational innovation due to the social changes that are generated through the years and the birth of the digital natives which make use of the web resources in an easy way and fast, for that reason the Flipped Classroom method which focuses its bases on the use of ICTs is evidenced as one of the teaching methods for the future. Fernandez and Barreira (2016) state that the influence of social changes in the educational system has highlighted the need for innovative pedagogical models through ICT. This study presents the results of an experience carried out with High Capacity students in Early Childhood Education making use of an flipped methodology as an innovative strategy based on the use of active learning skills to improve their potential using the digital world. (p.3)

On the other hand, the acquisition of vocabulary which is an essential component for the development of English language skills. For this reason it is very important to encourage the development and implementation of glossaries in the foreign language in the learners. At this point, Richardson (2009) states that the frequent finds for the vocabulary of everyday experiences is the main provision for the contextualized learning of unknown words. This is mainly due to the context-word relationship where the student can discern the importance and the general use of the word in its social sphere. (p.5). the author complements the above by outlining four steps for the introduction of unknown vocabulary. The author defines as unknown any word that has not been found in a reading in any of the previous sessions of the course. The four steps mentioned are: Define, Connect with a student experience, tell the story and use the word in another context.

On the other hand, the learning of vocabulary is fundamental in the process of teaching a second language and in that sense should emphasize the importance of the student in their independent role as this skill does not require any specific teaching by the teacher but it requires an autonomous and independent work in which its development has a total control of the student. Nation (1998) highlights that No matter what the teacher does or what the textbook says, in the end it is the student who learns. The results of vocabulary learning are much better if students take control and take responsibility for their own learning. Obviously, a teacher can never "transfer" new words to the student's long-term memory. (p 9-18)

In the same way, autonomy becomes a fundamental factor in the learning process of a language. The learning of vocabulary is an activity that must be developed autonomously and in it both teachers and students should look for different strategies that encourage the development of this skill and here both the Flipped Classroom method and the closed groups of Facebook play a fundamental role since they motivate the autonomous work. Strategies for learning are fundamental in the learning process. Wonka y Nunan (2011) state that the strategies for learning are fundamental in the learning process. In recent decades they have begun to provide and teach effective learning strategies, if the student is able to learn to study, he will be better 
prepared to continue learning the language also on their own outside the classroom.

For that reason, the Flipped Classroom promotes the autonomous work of the student from home and based on the tool of the closed groups of Facebook, which allows an interaction between students and teacher. Through this technological tool the teacher will be able to share the resources previously created in Quizlet and the YouTube tutorial videos that allow the students to be concentrated in a single study site so as to be able to be in constant contact with the resources to study before attending the class and give feedback on their own concerns or their classmates; It is to say, he / she will be able to attend classes with pre-knowledge which will make the class process different since it will be concentrated in both oral and written production and not in the study of specific topics.

Finally, being Facebook a social network so visited by young people nowadays and having a closed group with the students of a certain group with a common goal, it allowed to share audiovisual resources and followup on the part of the teacher so that the learning process is new, different, attractive, interactive, autonomous and invested in the current teaching processes.

\section{Method}

A quantitative research was developed, during the implementation process an initial diagnosis was applied to identify the vocabulary knowledge of the population, the diagnosis had some results, which were tabulated and analyzed. In addition, a reason for choosing the quantitative method is the need for numerical indicators to determine the academic performance of students in the practices where the use of specific vocabulary was involved; it is to say, the results showed the strengths and weaknesses obtained by the students.

Cortés and Iglesias (2004) The quantitative method takes numerical measurements as the center of its research process, uses observation of the process in the form of data collection and analyze them to answer the research questions. In this approach, Statistical Analysis is necessarily used. In relation to the above, it can be said that methodologically in the study two tests were designed (Diagnostic- KET 1 and final- KET 2) and finally, the results obtained by the students in the acquisition of vocabulary were systematized.

The population chosen for this research were 40 eight graders from a public institution in Colombia. The selection criteria were students with the lowest scores in the KET test and currently enrolled in the institution were the research was developed.

An action plan was established in order to respond to the phases established. Firstly, the diagnostic test was applied and important information was collected to determine the starting point of the students' knowledge of vocabulary at the beginning of the intervention by the KET test where students focused on parts 1, 2, 5 and 6 composed by vocabulary and reading comprehension through vocabulary. Secondly, a strategy based on the closed Facebook groups as an exchange of information environment and The Flipped classroom as a pedagogical 
approach were implemented to improve vocabulary learning. Finally, a second KET exam took place to see the improvement after the implementation process, the findings where discussed and analyzed in order to make a series of reflections and conclusions about the work carried out.

The instrument of data collection was the diagnostic test; according to Alderson (2005) the diagnostic test has the purpose of determining which competences the student acquired during his learning process, as well as how to use a second language in his daily activities. It is important to mention that the information provided by this test was used to make decisions about the improvements that must be made in the lesson plans and work in the classroom in the learning process.

Based on the above, the diagnostic test that was applied to the 8th grade students was the KET (Key English Test) in the version for schools, taking into account its evaluation components of reading and writing skills in part 1, 2, 5 and 6. (Fig. 1). This test was created by the University of Cambridge to assess A2 proficiency level in the foreign language according to the Common European Framework of Reference (CEFR). It is important to mention that Saber test 11 Test in English that is currently applied to all students in the country is also developed by the same university at its $\mathrm{B} 1$ level according to the CEFR.

\section{FINDINGS}

The first results are related to the Ket Test version 1 as a diagnostic test. The results found in the diagnostic test, show that 40 students of the Institución Educativa María Antonia Ruiz of Tuluá Valle del Cauca took the test and the results were: $1^{\text {st }}$ component $30 \%$ answered correctly, $2^{\text {nd }}$ component $32.5 \%$ answered correctly, $5^{\text {th }}$ component $43 \%$ answered correctly and $6^{\text {th }}$ component $49 \%$ answered correctly. The general result was $38.6 \%$ in the KET test applied in the 4 components of vocabulary assessment.

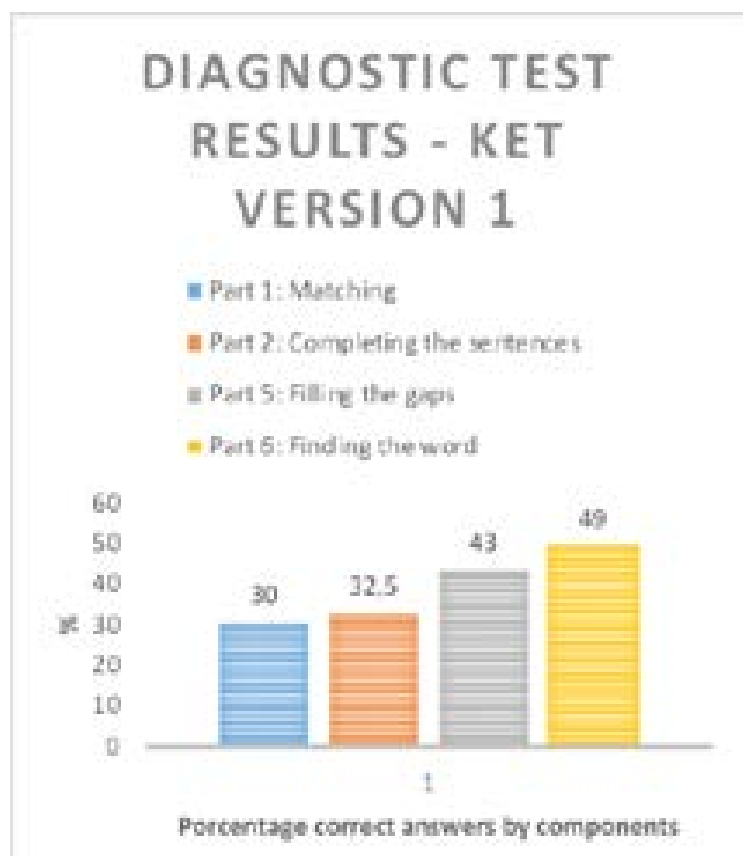

Fig. 1 Results of the diagnostic test - KET version 1

This result can be interpreted as not satisfactory and shows the lack of vocabulary that students had in the use of vocabulary in determined contexts according to the components evaluated in the test. As a final conclusion of the diagnostic test, the need to make changes in the curriculum of the 8th grade at Maria Antonia Ruiz School and adjust the specific vocabulary contents according to the MEN guidelines through the Guide 22 and 
implement a process of vocabulary acquisition in a striking and pleasant way to empower students with these components and improve vocabulary knowledge.

Once the strategy was implemented with students, the same test was applied in the second version as a final test in order to compare results to make a contrast between them. The final exam according to the Council of Europe (2001) aims to determine to what extent a student has achieved the specific learning objectives set for a specific period (a teaching unit, a month, a term, etc.) within the framework of a language course. This final test was

\section{FINAL TEST RESULTS KET VERSION 2}

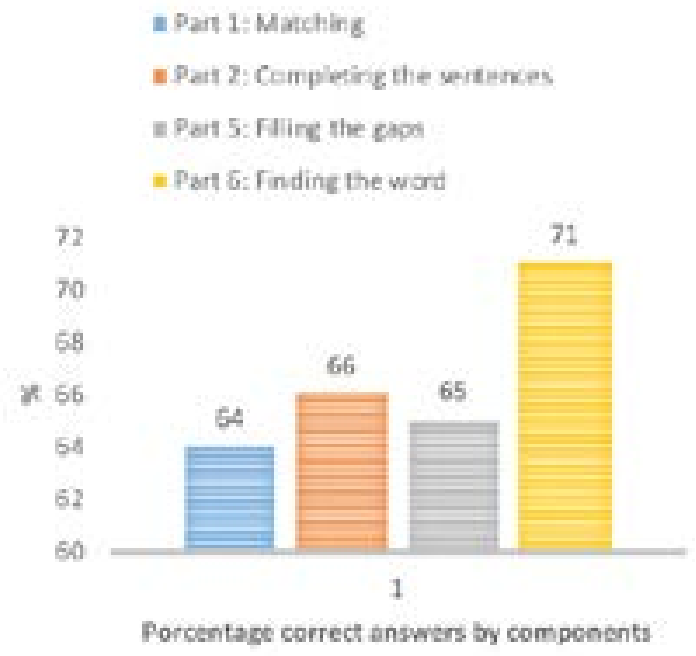

Fig. 2 Results of the final test - KET version 2

The final test shows the following findings: Overall, there was an improvement of $28 \%$ compared to the initial test. At the component level, the first component has an increase of $34 \%$, the second $38 \%$, the third $21 \%$ and last but not least, the fourth projected a $22 \%$ increase.

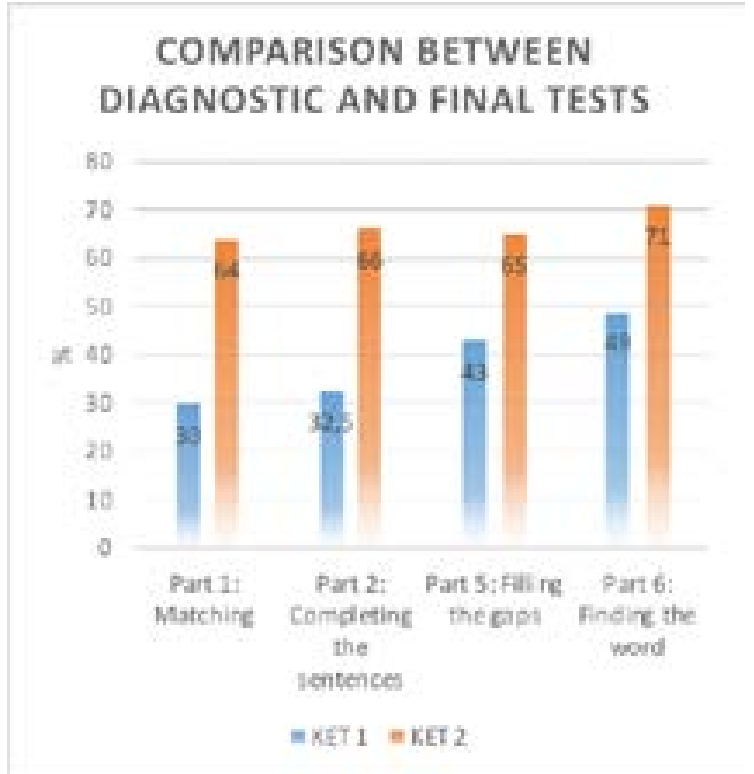

Fig. 3 Comparison between diagnostic and final tests

The above suggests that the guidelines drawn from the MEN by intermediation of the Basic Standards of Competence and the Basic Rights of Learning fulfilled in more than $50 \%$ of the population studied. This shows a significant advance for the researchers because of the precarious conditions described earlier in this investigation.

Regarding the variables exposed in the present study, it can be stipulated that in the dependent variable: Vocabulary in the English class, the follow-up is carried out through the diagnostic examination, which opens the way for knowing the weaknesses of the students in lexical terms and in this way, make an adequate selection of vocabulary to work during the the implementation in classes.

On the other hand, the independent variable: flipped classroom, is followed up through the 4 activities proposed in the implementation. These activities allow the student to consolidate the necessary vocabulary and improve the comprehension of the texts proposed during the face-to-face class. Which leads to an 
improvement in terms of vocabulary in the final test compared to the diagnostic test.

Finally, the $28 \%$ increase in the average of the components between the diagnostic test and the final exam suggests the verification of the hypothesis proposed in the current study. It says: The use of the Quizlet platform through the closed group of Facebook evidences significant results to the increase of vocabulary in foreign language of the eighth grade students of the I.E María Antonia Ruiz.

\section{DISCUSSION}

Relating to the research carried out by Nakata 2013 in its research Optimizing Second Language Vocabulary Learning from Flashcards learning second-language vocabulary from flashcards. it is possible to state that the implementation of the platform Quizlet was an essential part of vocabulary learning, even though the population did not have internet connection everywhere, they found the moments and environment. They also saw the strategy fun and of significant, stating that students managed to memorize a greater amount of words, aspect that is bearded out with the results gathered in this paper, relating the statement by Richardson (2009) when he affirms that the constant search for the vocabulary of everyday experiences is the main provision for the contextualized learning of unknown words. This is mainly due to the context-word relationship where the student can discern the importance and the general use of the word in its social sphere. In this report is visible the increasing results in vocabulary acquisition specially in finding the words and filling in the gaps strategies. This allows to confirm the use of closed Facebook communities is an appropriate strategy for developing vocabulary.

Addressing the research done by The Boarding University of China (2016) called The Adjustment and Effects of Vocabulary Teaching Strategies in Flipped Classroom, who proposes a Moodle platform based on Flipped Classroom approach to improve vocabulary learning through videos and conferences as a strategy, the research showed that they had a greater acquisition of vocabulary when vocabulary was studied by students at home, which corroborates the fact that through the Closed Facebook Groups and Quizlet it is possible to facilitate the learning of a foreign language as it was verified in this research work with the results of the final test, where it can be affirmed that the implementation of Quizlet produce a greater effect on vocabulary learning as it is affirmed by Nation (1998) the results of vocabulary learning are much better if students take control and take responsibility for their own learning.

Finally, the research carried out by AlHarbi1 \&. Alshumaimeri (2016), has several similarities with regard to the current research, since both investigations were developed in teenagers and both works have great relation when having the same approach Flipped Classroom and diagnostic and final tests. On one hand, the first of them was focused on grammar learning and this was focused on vocabulary learning, but both of them proved to be very assertive for the population intervened and showed improvement of vocabulary acquisition. It means, teachers should implement new strategies with teenagers because the way of teaching new generations have changed 
and students must take the main role of their learning process as Wonka y Nunan suggested (2011) In recent decades they have begun to provide and teach effective learning strategies ... If the student is able to learn to study, will be better prepared to continue learning the language also on their own outside the classroom. Findings about the strategies to learn vocabulary by students at the moment of reading is a proof of the development of learners' competence when they face new challenges.

\section{CONCLUSIONS}

According to the objectives set out in this research, in the first instance taking into account the first specific objective which refers to perform a diagnostic test to identify the current level of students in 8th grade in the process of acquiring vocabulary in English; It can be affirmed that the diagnostic examination revealed the imbalance in the specific contents of vocabulary and the need to optimize the process of reception and learning of the students.

Likewise, taking into account the second specific objective of this research that was to structure the area plan for the implementation of the Flipped classroom through the closed group of Facebook as an ICT resource, it can be concluded that the current teaching approaches in most of the cases do not go hand in hand with ICT resources since the teacher uses them within the classroom and there is a prohibition on student use since the good use of the resources is not encouraged. Similarly, traditional teaching processes do not promote the proper use of digital resources at home since in many cases students do not know how to use them for their intellectual enrichment at home, both individually and collectively. Hence Bergmann and Sams (2014) contribute significantly to this process. Their approach stipulates that flipped classroom is a pedagogical approach in which direct instruction moves from the collective learning space to the individual learning space, and the resulting space is transformed into a dynamic and interactive learning environment in which the educator guide students as concepts are applied and can participate creatively in the activities.

For the above and taking into account the third specific objective, which refers to sensitize students about the use and importance of ICT tools for the consolidation of the Flipped classroom, which leads to the learning of the language through the creation of the closed group of Facebook. It can be said that the creation of the closed groups of Facebook responds to the needs evidenced in the diagnostic examination and the awareness of the use and importance of the ICTs, allowing students an extra space within the common classes, preparing them to initiate an autonomous learning process, creating synchronous and asynchronous collaborative spaces of feedback with their peers and with the teacher. Reaffirming what has been said in the theoretical framework according to Jordan (2014) the growth of the use of new technologies should serve in learning contexts where the role of teacher-student can be exchanged and the student does not need the teacher to start or complement their learning process. 
On the other hand, taking into account the fourth specific objective which refers to implement four activities type flipped classroom for learning vocabulary in the closed group of Facebook through the use of the Quizlet platform; It can be concluded that the Quizlet platform validates its importance within the vocabulary learning process in this research with the percentage increase presented in the final test. by Nakata 2013 in its research Optimizing Second Language Vocabulary Learning From Flashcards learning second-language vocabulary from flashcards).

Based on the above, another contribution of the Quizlet platform to the research, which was portability, it is also confirmed. The possibility of being used both on the Android platform and on Windows facilitated students' access to vocabulary, it was an important part for learning vocabulary. This increase is reflected in the final test and in the asynchronous response of the Facebook platform, where students published their results opening a good competition in the classroom.

\section{BIBLIOGRAPHIC REFERENCES}

[1] Ministry of Education (2004). Bilinguism Program in Colombia 2004-2019.

[2] Alderson, J. Ch. (2003). «Diagnosing foreign language proficiency: a teaching / testing interface». Invited Presentation 38th SEAMEO RELC International Seminar, 03-05 November, 2003. EnL'avaluació dins I for a de l'aula. Barcelona: Generalitat de Catalunya, Secretaria de PolíticaLingüística, 2005, pp. $185-194$.

[3] Allen, Virginia French, (1983) Techniques in teaching vocabulary, Oxford: Oxford University Press.

[4] Bergmann, J., \&Sams, A. (2012). Flip your classroom: reach every student in every class every day. Washington, DC: International Society for Technology in Education.

[5] Bergmann, J., Sams, A. \& cols. (2014) What Is Flipped Learning? Flipped Learning Network (FLN). Disponible en: http://www.flippedlearning.org/ cms/lib07/VA01923112/Centricity/ Domain/46/FLIP_handout_FNL_Web. pdf

[6] Brown, C. and Payne, M. E., "Five essential steps of process in vocabulary learning," Paper presented at the TESOL Convention, Baltimore, Md., 1994.

[7] Carretero, A. (2005). Enseñar lenguas y aprender a comunicarse en contextos plurilingües y multiculturales/nuevas tecnologías y aprendizaje de las lenguas. Las TICS en el aula de inglés.

[8] Ciuffoli, C. (2010). Facebook como paradigma de alfatezación digital en tiempos de barbarie cultural. En A. Piscitelli y B. I. Adaime. El proyecto Facebook y la posuniversidad. Madrid: Ariel, pp. 111-128.

[9] Curbelo, Aury (21010). Digital education technology. Encontrado en la red en la siguiente dirección http://www.acurbelo. org/blogs/?p=100273

[10] Fernández del Río, A.B. y Barreira 
Arias, A.J. (2016). FlippedClassroom: Innovando en Educación Infantil con alumnado de Altas Capacidades.

[11]Flumerfelt \& Green, 2013. Using Lean in the Flipped Classroom for At Risk Students TOMADO DE http://www.ifets. info/journals/16_1/31.pdf

[12] Kang, N. (2015). The comparison between regular and flipped classrooms for EFL Korean adult learners. Multimedia-AssistedLanguageLearning, 18(3), 41-72.

[13] Eric Mazur (1997). Peer Instruction: A User's Manual Series in Educational Innovation.

[14] Nakata. T. 2013.Optimising second language vocabulary learning from flashcards unpublished doctoral dissertation. Victoria University of Wellington New Zealand. https://www. academia.edu/4557533

[15] Nation, Paul (1998). Helping learners take control of their vocabulary learning. GRETA 6(1): 9-18.

[16] Palmberg, Rolf, "Vocabulary development in foreign-language learners," Studies in Second Language Acquisition (Special issue: The Use and Acquisition of the Second Language Lexicon) 9/2 (1987a), Pp. 201-219.

[17] Richardson, J. (2009). The next step in guided reading. New York, NY: Scholastic Inc.

[18] Seal, Bernard D., "Vocabulary learning and teaching," Pp. 296-311, in Celce-Murcia, M. (Ed.) Teaching English as a Second or Foreign Language (2nd Ed.), Boston, MA: Heinle\&Heinle, 1991.

[19] Tedesco, J. C. (2009) Educar en la sociedad del conocimientoe. Bs. As: Fondo de Cultura Económico.

[20] Tourón, J., Santiago, R. \& col. (2013). "The Flipped Classroom" España: experiencias y recursos para dar 'la vuelta' a la clase. Disponible en: http://www.theflippedclassroom.es/

[21] Tourón J., Santiago R. y Díez A. (2014). The flipped classroom. Cómo convertir la escuela en un espacio de aprendizaje. Ebook: Grupo Océano. Recuperado CVC https://cvc. cervantes.es/ensenanza/biblioteca ele/publicaciones_centros/PDF/ napoles_2016/04_carrillo.pdf

[22] Vivando Verónica. (2001). La adquisición de vocabulario en una segunda lengua: Estrategias cognitivas y lazos afectivos.URL http:// encuentrojournal.org/textos/12.17.pdf

[23] Wilkins, David Arthur, SecondLanguage Learning and Teaching, London: Edward Arnold, 1974.

[24] Wonga, Lillian L.C. \& David Nunan (2011). The learning styles and strategies of effective language learners. System 39(2), 144-163

[25] Zhang, H. W., Li, J., Jiao, L. P., Ma, W. L., \& Guan, C. (2016). The Adjustment and Effects of Vocabulary Teaching Strategies in Flipped Classroom. Creative Education, 7, 1966-1973. http:// dx.doi.org/10. 4236/ce.2016.714199 